\title{
A Mediatised Conflict: The Mediatisation of Palestinian Split in Pan-Arab Transnational Satellite TV Journalism*
}

\author{
Hussein Al- Ahmad ${ }^{*}$
}

\begin{abstract}
This article explores the behind-the-scenes interplay between regional and Palestinian political actors through pan-Arab international satellite TV (PASTV) news media during the Palestinian internal conflict sparked in 2007 between Fatah and Hamas. The primary focus is on the influential role played by PASTV journalism in shaping the Palestinian political decision-making process during this interplay. The interplay between politics and news media forms the core discussion in the theory of 'mediatisation', which informs the theoretical framework in this article, also referring to such interplay as a struggle between 'political logic' and 'news media logic'. Such a struggle reflects the difference between "neutral" and "participant" journalism and how that might influence political processes and political culture. From an informant's perspective, the article examines how such transnational political communication took place, and the aims each political player attempted to achieve through the mediated reality shaped in PASTV journalism. The study demonstrates with evidence how the role played by PASTV journalism was not an accidental occurrence but an extension of their regional financers' interests in the conflict. While trying to reinforce the political clout of their Palestinian ally and maximize public sympathy toward this position, the exacerbation and perpetuation of the split become consequences.
\end{abstract}

Keywords: Mediatisation, Transnational TV Journalism, Media Logic, Political Logic, Mediated Reality

An earlier version of this work has been presented in the proceedings of: The Fifth Middle East Congress on Politics and Society, Middle East Institute, Sakarya University, Turkey, November 14-15, 2020.

** Dr., Head of Media Communication Department, Faculty of Graduate Studies, Arab American University, Palestine (P.S.), orcid.org/0000-0001-5347-9965, hussein. alahmad@aaup.edu 


\title{
Arabuluculuk Çatışması: Pan-Arap Uluslararası Uydu TV Yayıncılığının Aracılığıyla Filistin Bölünmesinin Arabuluculuğu*
}

\author{
Hussein Al- Ahmad
}

Öz

Bu makale, 2007 yılında Filistin'de El Fetih ve Hamas arasında patlak veren iç çatı̧̧ma sırasında, Pan-Arap uluslararası uydu TV (PASTV) haber yayıncılığı aracılığıyla bölgesel ve Filistinli siyasi aktörler arasındaki perde arkası etkileşimi araştırmaktadır. Makale öncelikle PASTV basının bu etkileşim sırasında Filistin'in siyasi karar alma sürecini şekillendirmede oynadığı etkili rolün üzerine yoğunlaşmaktadır. Siyaset ve haber yayıncıllğı arasındaki etkileşim, bu makaledeki teorik çerçeveyi yani 'arabuluculuk' teorisindeki temel tartı̧̧mayı oluşturmaktadır, aynı zamanda makale 'siyasi mantık' ve 'haber yayıncılığı mantığı' arasındaki etkileşimi bir çatışma olarak değerlendirir. Böyle bir çatışma, "tarafsız" ve "katılımcı" basın arasındaki farkı ve bunun siyasi süreçleri ve siyasi kültürü nasıl etkileyebileceğini yansıtır. Makale, bir muhbirin bakış açısıyla, bu tür uluslararası siyasi iletişimin nasıl gerçekleştiğini ve her siyasi oyuncunun PASTV basınının şekillendirdiği gerçeklik aracılığıyla elde etmeye çalışı̆̆ı̆ hedefleri incelemektedir. Makale, PASTV basının oynadığı rolün tesadüfi olmadığını, bölgesel finansörlerin çatışmadaki çıkarlarının bir uzantısı olduğunu kanitlamaktadır. Filistinli müttefiklerin siyasi nüfuzunu güçlendirmeye ve halkın sempatisini kazanmaya çalışırken, bölünmenin alevlenmesi ve devam etmesi sonuç haline gelmiştir.

Anahtar Kelimeler: Arabuluculuk, Uluslararası TV Yayıncıllğı, Medya Mantığı, Siyasi Mantık, Aracılı Gerçeklik

Beşinci Orta Doğu Siyaset ve Toplum Kongresi bildirisinde sunulmuştur. Orta Doğu Enstitüsü, Sakarya Üniversitesi, Türkiye, 14-15 Kasım 2020.

** Dr., Stratejik İletişim Bölüm Başkan1, Arap Amerikan Üniversitesi, Lisansüstü Eğitim Fakültesi, Filistin, orcid.org/0000-0001-5347-9965, hussein.alahmad@aaup.edu 


\section{Introduction}

In an era of fake news and increasing authoritarianism, the realm of news media became identified by syntheses of corporate and political capital with modern technology, producing an attractive and powerful media spectacle. ${ }^{1}$ Scholars of the mediatisation theory emphasize media dependency, media attention and related hypotheses as products of the TV era. ${ }^{2}$ Satellite TV has become an influential medium of our time, ${ }^{3}$ more capable than at any other time of gaining the attention of massive audiences. ${ }^{4}$ In the Middle East, with its increasing turbulence, authoritarianism and political competition, systematic propaganda was in high demand amongst regional ideologies competing for territorial dominance. With its comprehensive and powerful influence, pan-Arab transnational satellite TV (henceforth PASTV) journalism outweighed most other means of attracting public attention. ${ }^{5}$

This article examines the role played by PASTV journalism in covering news of the recent Palestinian internal conflict over power and identity. The article draws on primary qualitative data gathered through thirty semi-structured interviews with high profile stakeholders and key players in Palestinian politics and the media industry, identified as 'the informants'. ${ }^{6}$ In recruiting these participants/informants, three main

Meenakshi G Durham and Douglas M Kellner, Media and Cultural Studies (Malden, MA, USA; Oxford, UK; Carlton, Australia: Blackwell Publishing, 2006).

2 Winfried Schulz, "Reconstructing Mediatization as an Analytical Concept," European Journal of Communication 19, no. 1 (2004): 94, https://doi. org/10.1177/0267323104040696.

3 Schulz, "Reconstructing Mediatization as an Analytical Concept."

4 Jesper Strömbäck and Frank Esser, "Shaping Politics: Mediatization and Media Interventionism," in Mediatization. Concept, Changes, Consequences, ed. Knut Lundby (New York: Peter Lang, 2009), 209, https://doi.org/10.5167/uzh-29325.

5 Mohamad H. Elmasry et al., "Al-Jazeera and Al-Arabiya Framing of the IsraelPalestine Conflict during War and Calm Periods," Communication Gazette 75 (2013): 765, https://doi.org/10.1177/1748048513482545.

6 The informants are prominent media researchers, news producers and analysts, newscasters, academic scholars in the two fields of politics and media. There was also the correspondents for key PASTV as well as other regional and international news agencies, in addition to media observers and journalists from civil society research centers. Further interviews targeted, as much as it was possible, the PASTV channels' editorial and managerial staff, as well as their field correspondents in Palestine. For confidentially, informants' testimonies were anonymously quoted, and addressed by their job titles. 
defining characteristics were sought: Professional profile/position (field and years of expertise, and connection with political and media policy makers); citizenship and geographical location (Palestinians in Gaza \& West Bank); and, for key political actors, their belonging to a particular party, civil society organization or independent bodies. Accordingly, my sample included participants with varied, but also relevant backgrounds and expertise. The aim is to examine the interrelationships between regional political powers along with their affiliated Palestinian parties, through PASTV broadcast, in one of the most divided stages in Palestine's already fragmented political culture. Primary focus in this article lies on the behind the scenes interplay between the regional and domestic political actors through PASTV journalism; i.e., the interplay, or struggle, between "political logic"7 and "news media logic' ${ }^{8}$ over the issue of news production, and how that was reflected in PASTV journalism while covering the news of the split. The behind the scenes interplay is one of the most important areas of journalism studies as according to the theory of mediatisation, it is an area that facilitates the examination of the interaction between news media messages and political actors. ${ }^{9}$ The significance in considering the value behind the treatment and reproduction of news lies in that "it goes to the heart of what is included, what is excluded, [also how] and why". ${ }^{10}$ The study also explores the aims driving the way news was produced/framed. In this regard, the theory of mediatisation deals primarily with how media has the power to 'shape' and 'frame' the political communication discourse and public attitudes. ${ }^{11}$ In the same context, the literature on the framing of

The political logic as conceptualized by Esser and Matthes (2013) is a concept formed by three spheres, these are: "Polity, policy and politics. Polity refers to the system of rules regulating the political process in any given country, including the institutional structure.

8 According to Strömbäck (2008), Media logic is: "The dominance in societal processes of the news values and the storytelling techniques the media make use of to take advantage of their own medium and its format, and to be competitive in the ongoing struggle to capture people's attention," 233.

9 Deirdre O'Neill and Tony Harcup, "News Values and Selectivity," in Handbook of Journalism Studies, ed. T Hanitzsch (Hoboken, NJ: Routledge, 2009), 161-74.

10 O'Neill and Harcup, 162.

11 Toril Aalberg, Jesper Strömbäck, and Claes H. De Vreese, "The Framing of Politics as Strategy and Game: A Review of Concepts, Operationalizations and Key Findings," Journalism 13, no. 2 (2012): 163-65. See also: Darren G Lilleker, "Mediatization," in Key Concepts in Political Communications (London: SAGE, 2008), 117-21, http:// dx.doi.org/10.4135/9781446212943.n29. 
news discusses how, through framing, news media not only narrow the choices of current events with which the audience can engage, but it further suggests how they should think about them. ${ }^{12}$ Moreover, as argued by de Vreese, the intersection between framing and mediatisation is evident, in particular by showing how "journalistic news framing is a key indicator of mediatization, and reflect on the consequences of different types of news framing". ${ }^{13}$ As such, framing offers news media huge potential to intervene and shape viewers' perceptions and opinion of the issues framed within the news. Identifying the aims behind the framing of news helps in understanding how that interplay facilitated the channels' endeavor to shape the Palestinian political decision-making process.

Basically, the analysis considers two conditional and interrelated variables in that interplay; the first relates to the 'value' that political powers sought in the journalism on PASTV channels and the second relates to the 'needs' that PASTV channels aimed to meet by adhering to the 'will' of the political powers and by adopting their agendas. These variables were analyzed by considering the following questions: What 'value/s' did the regional political powers seek in PASTV journalism? And, what 'need/s' did PASTV channels aim to meet by adapting their journalism to fit the policy of the political powers? How did the value and need interplay? How was it reflected on Palestinian political culture?

\section{Literature Review}

The two most leading forms of news media in our time are primarily social media and satellite TV; ${ }^{14}$ both are areas of consideration in the theory of 'mediatisation of politics'. Initial efforts to engage with the role of mediatisation in politics came by the Swedish media researcher Kent Asp,

12 See: Claes H de Vreese, "Mediatization of News: The Role of Journalistic Framing," in Mediatization of Politics: Understanding the Transformation of Western Democracies, ed. Frank Esser and Jesper Strömbäck (London: Palgrave Macmillan UK, 2014), 13755, https://doi.org/10.1057/9781137275844_8. See also: Raychuk, "Framing, AgendaSetting and Priming in Media". Robert Entman, "Framing: Toward Clarification of a Fractured Paradigm," Journal of Communication 43, no. 4 (1993): 52.

13 de Vreese, "Mediatization of News," 137.

14 Walter Armbrust, "A History of New Media in the Arab Middle East," Journal for Cultural Research 16, no. 2-3 (2012): 155, https://doi.org/10.1080/14797585.2012.64 7666. 
who emphasized its role in shaping public opinion. ${ }^{15}$ In 1995, Thompson argued how the increase of communication media has transformed forms of social interaction, and brought new forms of interaction, with new kinds of social relationships that generated the reorganization of human interactional patterns. ${ }^{16}$ Krotz and Hepp, combined empirical research outcomes and theoretical reflections scrutinizing the growing influence of media on people's lives. ${ }^{17}$ Similarly, Hjarvard discusses mediatisation as an agent for sociopolitical change. He argues that mediatisation arose as a powerful theory aimed at revisiting the role and influence of media on culture and society, primarily through politics. ${ }^{18}$ How this role interplays in conflicts was also highlighted by a team of communication experts, who joined the 'Media, Conflict and Democratisation' (MeCoDEM) project involving communication schools at eight international universities. ${ }^{19}$ The team examined case studies on the role that media plays in various conflicts, chiefly those in a process of transition. This perspective was also emphasized during the last two decades in the works of other scholars like Jenssen and Aalberg, ${ }^{20}$ also by Strömbäck, ${ }^{21}$ and Cottle where they examined the crucial role of news media involvement, and whereby Cottle termed 'mediatized conflicts. 22

In Manufacturing Consent, ${ }^{23}$ Herman and Chomsky discussed news media in contextual characteristics similar to those in the states hosting PASTV

15 Kent Asp, Massmedier Mäktiga: Studier i Politisk Opinionsbildning Powerful Mass Media: Studies in Political Opinion-Formation (Stockholm: Akademilitteratur, 1986), 359.

16 John B Thompson, The Rise of Mediated Interaction (UK: Cambridge, 1995).

17 Hepp Andreas and Friedrich Krotz, Mediatized Worlds: Culture and Society in a Media Age (UK: Palgrave Macmillan, 2014), https://doi.org/10.1177/0163443716667063.

18 Andreas and Krotz, Mediatized Worlds, 5.

19 The project is an EU funded project, managed by key communication departments at eight prominent universities: Leeds, Belgrade, Hamburg, Cape Town, Oxford, Stockholm, Ruhr University Bochum and the American University in Cairo. http:// www.mecodem.eu/about/introduction/

20 Anders T Jenssen, Den Medialiserte Politikken [Mediatized Politics] (Oslo: Universitetsforlaget, 2007).

21 Jesper Strömbäck, "Four Phases of Mediatization. An Analysis of the Mediatization of Politics," The International Journal of Press/Politics 13, no. 3 (2008): 228-46, https:// doi.org/10.1177/1940161208319097.

22 Nidhi Shendurnikar and Simon Cottle, Mediatized Conflict: Developments in Media and Conflict Studies, ed. Simon Cottle (UK: Open University Press, 2006).

23 Edward Herman and Noam Chomsky, Manufacturing Consent: The Political Economy of the Mass Media (New York, USA: Pantheon Books, 1988). 
channels. The writers explain how the role of media in the new world identified by centralized wealth and state besides class conflicts of interest - have changed dramatically, generating what they conceptualize as 'systematic propaganda'. This is a paradigm likely to operate in countries where the political elite have the upper hand over media and so the "media serve the ends of the dominant elite." ${ }^{24}$ They also propose the private media model, where media sources tend to portray themselves as "spokesmen for free speech and the general community interest." ${ }^{25}$ Herman and Chomsky's main concern about this type of media is the "huge inequality in command of resources" and how this affects the role of private media and its performance amid the new challenges of financing versus objectivity. ${ }^{26}$ Herman and Chomsky's paradigm also stresses the ways money and power decisively intervene to filter out the news to fit with the government's (as well as the dominant private elite's) desire to impose influence on the public. The authors also show how media in the new context is manipulating the premise of news discourse and interpretation, as well the definition of what is newsworthy. This manipulation takes place through the editorial process and successive filtering, leaving the 'cleansed residue' that fits with the interests of the dominant powers.

In mediatisation, the relationship between media and politics is discussed as an interplay between political logic and news media logic, ${ }^{27}$ which is also an area of research that makes the very essence of the mediatisation of politics and mediatised conflicts. ${ }^{28}$ While renowned contributors to the field see the relation between both logics as complementary, ${ }^{29}$ however, for others it is a struggle over the news message; Strömbäck for example,

24 Edward Herman and Noam Chomsky, "A Propaganda Model (Excerpted from Manufacturing Consent: The Political Economy of the Mass Media)" (https://chomsky. info, 1988), 43, https://chomsky.info/consent01/.

25 Herman and Chomsky, "A Propaganda Model," 43.

26 Ibid.

27 Strömbäck, "Four Phases of Mediatization."

28 Strömbäck and Esser, "Shaping Politics: Mediatization and Media Interventionism." See also: Strömbäck and Aelst, "Why Political Parties Adapt to the Media: Exploring the Fourth Dimension of Mediatization" (2013).; Cottle, Mediatized Conflict: Developments in Media and Conflict Studies, (2006); Wolfsfeld, Media and Political Conflict: News from the Middle East, (1997).

29 See: March and Olsen, Rediscovering Institutions, (1989); see also: Jennifer Ostini and Anthony Y.H. Fung, "Beyond the Four Theories of the Press: A New Model of National Media Systems," Mass Communication and Society 5, no. 1 (2002): 41-56, http://dx.doi.org/10.1207/S15327825MCS0501_4. 
discusses it as a long-term process of four phases, in which the role of media shifts from a major source for information -in the communication process between public and politicians- to the fourth estate. ${ }^{30}$ The interplay between the two logics develops accordingly, and gradually, news media become more independent and, according to Cook, is able to argue the issue of newsworthiness against political attempts to impose influence on the news production. ${ }^{31}$ Notwithstanding, the role of news media does not evolve in isolation from its milieu. While in the case of Strömbäck, media role is examined in democratic contexts, in covering the Palestinian split (a Middle East nondemocratic context), the correlation between the political logic and news media logic is likely to perform in a different way; mostly scarifying objectivity while serving the ends of dominant elites, as discussed earlier by Herman and Chomsky. So, this study has placed the interplay between power holders in political and news media institutions (political logic and news media logic) into the theoretical mix of media control, attention and operation, as the essence of the 'mediatisation of politics.'

Emphasizing the societal impact of such 'politics - news media' interaction is crucial. In News That Matters, Iyengar and Kinder explain how audiences' views of national priorities are powerfully shaped by TV news media, primarily through emphasizing certain stories over others within the TV news. ${ }^{32}$ Iyengar and Kinder's experiment with agenda-setting shows how exposure to both agenda-setting and priming are powerful enough to change opinion. There can be a dramatic shift within a nation regarding its priorities and the issues people judge as most important for their country. The writers explain how the positioning of a story in a television news broadcast can affect its importance - with the audience perceiving lead stories as being most newsworthy. The authors further offer a new perspective on the issue of priming; "supposing how television news might be a powerful determinant of what comes to mind and what is

30 Strömbäck, "Four Phases of Mediatization. An Analysis of the Mediatization of Politics."

31 Timothy E. Cook, Governing with the News. The News Media as a Political Institution, 2nd ed. (Chicago: University of Chicago Press, 2005), 61-63.

32 Shanto Iyengar and Donald R Kinder, News That Matters: Television and American Opinion (Chicago, IL, US: University of Chicago Press, 1987). 
forgotten or ignored," ${ }^{33}$ primarily when the public evaluates complex and emerging political problems. In summary, Iyengar and Kinder examine how television news establishes conditions which affect people's political judgments and choices. They experimentally demonstrate how TV news became an intervening authority affecting and shaping the criteria by which political issues are measured and voters' choices are made. In Mediatized Conflict, Cottle offers a close insight into the principal theoretical approaches applied in the study of news media role in conflict coverage. ${ }^{34}$ However, Durham and Kellner in Media and Cultural Studies, ${ }^{35}$ explain how 'media culture' intervenes in our daily life aspects, shaping news messages, as well, forming social meanings and identities. The influence of media consumption receives focal interest in their work, mainly how meanings and identities are reflected in media screens, creating a great opportunity for sociocultural disputes to be waged by news media.

The news making in PASTV media, and its role in community and politics, become more comprehensible when taking into account either end of the historical developments occurred in Middle East's mass media landscape, and scholarship on new media, primarily Satellite TV, as they have unfolded over the past two decades. ${ }^{36}$ According to Rugh, although media systems in the Arab world widely vary in terms of governing regulation, also in levels of competence and independence in journalism, however, most of these systems share similarities, primarily in terms of ownership, loyalty to ruling elites, and political alignment, as apparent features in these systems. ${ }^{37}$ Rinnawi referred to the term 'McArabism' to address the interaction between technological and contextual factors, creating the convergence of domestic tribal identities with globalization, reproducing a new regional Arab identity. ${ }^{38}$ According to Leihs and Roeder-Tzellos,

33 Iyengar and Kinder, News That Matters, 114.

34 Simon Cottle, Mediatized Conflict: Developments in Media and Conflict Studies (UK, Glasgow: Open University Press, 2006).

35 Durham and Kellner, Media and Cultural Studies.

36 Cottle, Mediatized Conflict, 155.

37 William A Rugh, Arab Mass Media: Newspapers, Radio, and Television in Arab Politics (Westport, CT: Praeger, 2004).

38 Khalil Rinnawi, Instant Nationalism: McArabism, Al-Jazeera, and Transnational Media in the Arab World (University Press of America, 2006), https://books.google. ps/books?id=xJYLNUBgSeUC. 
"early on, the ruling Arab elites identified the media as a tool to organize support for their political, economic, and social objectives." ${ }^{39}$ News media was almost entirely in the hands of state power and serving its ends, which practiced organized severe forms of censorship and regime domination over media. ${ }^{40}$

The post-Oslo era and the new political system that emerged in the West Bank and the Gaza Strip after 1994 can be identified as one "authoritarian, dominant by PA, and another civic democratic but passive and overshadowed by the first." ${ }^{21}$ This continued until the 2006 elections, which formed a direct cause of the split. ${ }^{42}$ These new realities have created profound changes and identity crises. Crucially there was a shift in the way the Palestinians themselves communicated with and perceived each other. By the beginning of the split in 2006, there were primarily three main PASTV news channels; Aljazeera based in Qatar, the Saudi-owned Alarabiya channel based in the United Arab Emirates (UAE), and the Hezbollah channel Al-Manar based in Lebanon. If the split timeline is considered, it can be seen that two thirds of the timeline involved the regional conflict (and other splits) in the Arab world after the 2011 uprisings. The accelerated developments during and beyond 2011 changed the priorities in the states that sponsored or hosted PASTV channels. This was directly reflected in the editorial policy of these channels, including their coverage of the developments in the Palestinian conflict, and eventually, a channel's position from the two Palestinian rival parties involved in the split.

39 NadiaLeihsandMariaRoeder-Tzellos, "PoliticalCommunicationResearchin the Middle East," in The International Encyclopedia of Political Communication (NJ, United States: John Wiley \& Sons, Inc., 2015), 2, https://doi.org/10.1002/9781118541555. wbiepc211.

40 Marc Lynch, "Shattering the 'Politics of Silence': Satellite Television Talk Shows and the Transformation of Arab Political Culture" (Washington, DC: SADA: Carnegie Endowment for International Peace, 2008), http://carnegieendowment. org/sada/?fa=21036. See also: Magdalena Wojcieszak, "Al-Jazeera: A Challenge to Traditional Framing Research," The International Communication Gazette 69, no. 2 (2007): 115-28.

41 As'ad Ghanem, The Palestinian Regime: A "Partial Democracy" (Brighton, Portland: Sussex Academic Press, 2001).

42 National Democratic Institute for International Affairs, "Final Report on the Palestinian Legislative Council Elections" (Washington DC: national democratic institute, 2006). 


\section{A Systematic Propaganda: Catering Political Powers}

During the interaction between politics and news media, in the aftermath of the Palestinian split, then the 'Arab Spring', the aims of media organizations and political powers intersected through news production. In order to fit both the political interests of the regional powers and the needs of PASTV channels, the developments in the Palestinian split and the narratives of the two parties were presented, within PASTV journalism, through designated frames, ${ }^{43}$ that are structured in a way to serve the ends of a channel's financer. News stories were selected and treated based on their potential to add the 'news value' that is laden with political influence. The theory of mediatisation refers to this process as a struggle between political logic and news media logic. ${ }^{44}$ Analysing such a struggle is necessary to consider the democratic implications of external political and media interventions, and also their direct impact on the Palestinian fragmented political culture, as well as the future of the conflict.

\section{Figure 1: Key players in the interplay between Palestinian and regional political elites through PASTV journalism, as seen by the informants of this study.}

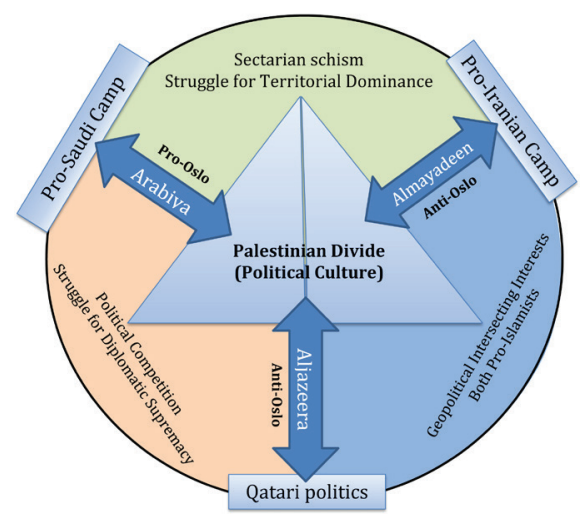

43 Deirdre O'Neill, “What Is News?,” Journalism Studies 18, no. 12 (2017): 1474, https://doi.org/https://doi.org/10.1080/1461670X.2016.1150193. See also: Jesper Strömbäck and Lars W Nord, "Do Politicians Lead the Tango?," European Journal of Communication 21, no. 2 (2006): 147-64.; Frank Esser, "Metacoverage of Mediated Wars: How the Press Framed the Role of the News Media and of Military News Management in the Iraq Wars of 1991 and 2003," American Behavioral Scientist 52, no. 5 (2009): 709-34, http://online.sagepub.com.

44 Strömbäck, "Four Phases of Mediatization." 
Reflecting on primary data shows that, the majority of informants judged PASTV coverage to be interventional, also serving certain interests of channels' financers involved in the Palestinian split, which can be classified as having two major aims:

1. Reinforce the political stand and clout of the Palestinian ally, and

2. Maximize the degree of public sympathy for the ally.

Both aims embodied the geopolitical interests of the two regional camps. To achieve these aims, PASTV channels were doing what field scholars call the "framing of news. ${ }^{45}$ The split developments were presented to Palestinians engrossed in the conflict, through designated frames, as the 'reality'. For Entman (1993), those frames work as mechanisms "to promote a particular problem definition, causal interpretation, moral evaluation, and/or treatment recommendation' ${ }^{46}$ In this way, the channels were skillfully converting the developments occurring during the split into 'news value' in their journalism, which was produced to fit their financers' political desires. The following discussion considers how PASTV journalism attempted to achieve its two key political interests, also the motives behind these attempts.

\subsection{Media Intervention: Reinforcing an Ally's Political Stand}

Meyer et al. (2017) examined six ongoing conflicts similar in main characteristics to the Palestinian split. They concluded that, the role played by news media in supporting actors involved in these conflicts was contingent upon two main factors: 1) "On the ways in which it transforms conflict actors' claims, interpretations and prescriptions into media content," and, 2) "Their ability to amplify these contents and endow them with reach, visibility and consonance." ${ }^{\prime 7}$ Given the high degrees of compatibility between these six conflicts and the Palestinian split, it is reasonable to adopt these two central factors as two main indicators that

45 Robert Entman, "Framing: Toward Clarification of a Fractured Paradigm," Journal of Communication 43, no. 4 (1993): 51-58.

46 Entman, "Framing."

47 Christoph O Meyer, Christian Baden, and Marie-Soleil Frère, "Navigating the Complexities of Media Roles in Conflict: The INFOCORE Approach," Media, War \& Conflict 11, no. 1 (2017): 17, https://doi.org/10.1177/1750635217719754. 
will help investigate whether, how and to what degree, they were embodied in PASTV coverage of split incidents.

\subsubsection{Spinning the Narratives of Palestinian Rivals into 'News'}

PASTV coverage of the split was characterized by two main factors; the representation of events based on the sponsor's position towards a certain Palestinian party; and how that event related to channels' financer and their contested interests in Palestinian politics. The reflection on the informants' testimonies identifies empirical evidence confirming that i) certain news stories were intentionally selected based on the requirements of financers, and ii) the claims and perceptions of the two Palestinian parties were the key focus within PASTV newscasts. As seen by the informants, news treatment targeted public opinion and key figures within the two parties, in support of channels' domestic ally; this embodied a key interest for their financers. This further offered Palestinian rivals an opportunity to utilize the PASTV channels that belonged to their regional ally to propagate their claims and gain public sympathy. ${ }^{48}$ News programs and talk shows offered convenient stages for the political actors to mobilize their public, but they were also convenient platforms for PASTV channels to intervene in the politics of the two parties. Aljazeera's Kashf El-Mastoor (Revealing the Hidden) embodied a model of this contentious type of PASTV news program. ${ }^{49}$ Other channels also had similar talk shows - Alarabiya's Eda'at (Spotlights), Mirat Alsahafa (Press Mirror) and Almayadeen's Kalima Horra (Free Word) hosted in London by George Galloway. All these influential talk shows served as attractive platforms that attracted public attention. The discussions with several informants emphasized how Palestinians' habitual pursuit of these powerful news programs, led them to become victims of the 'mediated reality' presented within the news. "The round-the-clock broadcasts, with their inclusive coverage and powerful news messages, meant the channels' journalism was a convenient tool for

48 Former Palestinian MP and Fatah Party Leader, "Former Palestinian MP and Fatah Party Leader" (Ramalla, Palestine: Interview by Hussein Alahmad, November 28, 2018, 2018).

49 As stated by a Palestinian Columnist and News Analyst, "Informant" (Interviewed by Hussein Alahmad, December 19, 2019, 2018). 
marketing regional agendas. Look how for a decade now the reconciliation process was always thwarted." ${ }^{\circ 0}$

During several rounds of attempts to achieve a settlement to the conflict, the negotiations between Palestinian rivals were thwarted by obstacles. These obstacles included PASTV involvement in supporting one party against another. The channels provided 'sponsor-oriented coverage', which would change in tandem with changes in the position of financers: "The Egyptian channels for instance played the worst role in this regard, further than adopting partisan narratives; they practiced defamation and incitement against each other." ${ }^{51}$ This example and some others show how the region was a dynamic political situation in which Arabian political interests were constantly shifting, like drifting Arabian sand, and respectively, the policy of PASTV channels was always fluctuating while reporting an ally's storyline. The political pressure in certain cases, and the 'grant-inaid,' were likely to give the hosting state a large potential to exercise its influence through its channel's news - thus, supporting the political stand of its Palestinian ally. Regional powers have a direct influence on channel editorials, and such pressures were clear in PASTV coverage. ${ }^{52}$ PASTV journalism was powerful, attractive, and influential for its audience. ${ }^{53}$ The skillful editorial teams and huge capacity to provide comprehensive news, maximized PASTV audiences - and to satisfy their financers, their news messages were laden with regional influence. According to a Palestinian news reporter, geopolitical interests were strongly felt in PASTV journalism: "the channels were acting as 'mobilizers and polarizers,' more than informers." ${ }^{54}$

PASTV channels were intentionally publicizing contradictory Palestinian narratives, such as the disarming of Hamas and the unifying of security

50 Dean at a Palestinian Media College, "Informant" (Interview by Hussein Alahmad, November 21, 2018).

51 Dean at a Media Department in a Palestinian university, "Informant" (Interviewed by Hussein Alahmad, December 13, 2018).

52 Palestinian Media Analyst at Key Policy Research Center, "Informant," ed. Hussein Alahmad (Interviewed by Hussein Alahmad, November 23, 2018).

53 Palestinian correspondent for a PASTV Channel, "Informant" (Interviewed by Hussein Alahmad, December 14, 2018).

54 Palestinian Media Reporter at an NGO, "Informant," ed. Hussein Alahmad (Interviewed by Hussein Alahmad, November 27, 2018). 
forces.The way competing narratives were produced and presented, or 'framed', was exacerbating the divided audience and so worked to expand the gap between the two parties; "In several crucial events during the conflict, the channels utilized spokesmen, pundits and news analysts affiliated with the two parties while hosting within their talk shows and newscasts. The hosts were leading the debate in a designated way to impose certain regional influence or raise certain financers' interests pertinent to one party against the other during those events." ${ }^{" 55}$

While Palestinian actors were eager to be hosted by these channels to tell their stories, both Palestinian leadership and public opinion were targets for regional agendas. The channels would propagate the claims of their affiliated party towards a certain event, whilst criticizing the position of their rival. Propagating such claims was continuously sparking contention amongst the Palestinians. It was a two-way traffic of political message transmission between regional and domestic politics, in which domestic politics was the underdog. Discussions with several informants identify that most channels practiced 'gatekeeping' based on its donor's priorities, although with varied levels and styles. PASTV channels adopted the story of one party and denied that of other. Furthermore, the discussion with correspondents of several channels identifies how their policies and editorial instructions were ordained by the financers, rather than by professional standards; "We used to ignore some news and only take that which fitted the channel's policy. [...] in certain events some news was bypassed, while other news was taken seriously; we favored certain news to the advantage of the party we supported." ${ }^{56}$

In covering such a sensitive conflict, the imperative for journalism is to cover events based on the available evidence, not based on the state or sponsor's position towards the rivals. It might be plausible for objectivity and neutrality in journalism not to be always juxtaposed. This is chiefly because it might not be possible, in a story with such humanitarian dimensions such as that in Gaza Strip, to take a position that is even handed. Sometimes also, if events were reported in an entirely balanced way, then it might be very hard for the viewer to draw a conclusion from what was happening. Thus, the essential issue in such a case is objectivity; how

\footnotetext{
55 Palestinian Media Analyst at Key Policy Research Center, "Informant."

56 Palestinian correspondent for a PASTV Channel, "Informant."
} 
the truth is determined and communicated, rather than whether a channel appears neutral or not. In covering Palestinian split, the state's influence on the channel's editorial policy was tangible. Arguably, this means that political logic dominated over news media logic.

\subsubsection{Media Attention: Amplifying the Parties' Narratives}

In order to achieve their aim of supporting the political stand of their Palestinian allies, the parties' narratives have to gain sufficient momentum to attract public attention. The victory of an ally was a victory for his regional supporting camp. This means that the channels lining up behind the two regional camps competed against themselves to attract public attention, principally through priming the news pertaining to their ally's claims and interpretations of the split developments. Among other techniques, news pertaining to the ally was presented within the headlines and continuously reported to reinforce its importance. This type of coverage penetrated the awareness of Palestinians and reinforced their partisan affiliations. ${ }^{57}$

PASTV channels were intervened in the conflict's political trajectory and participated in shaping Palestinian public opinion and political participation. Such intervention was promoted by the interests of the channels' financers in the conflict. ${ }^{58}$ The news about split events was laden with regional political influence that targeted public opinion, as well as decision making within the two parties. The channels adopted the positions of two Palestinian parties when covering contested issues during the conflict. Furthermore, PASTV editorials aligned these narratives to the interests of their financers. ${ }^{59} \mathrm{~A}$ Palestinian party leader also emphasized the role of the channels in augmenting the importance of certain information that was filtered and made more attractive: "Those channels magnified the internal conflict by working as a platform for partisan polarization and incitement against each other. [...] Aljazeera referred to erudite politicians

57 Director of a Palestinian Center for the Protection of Press Freedom, "Informant" (Interviewed by Hussein Alahmad, December 24, 2018).

58 PLO Executive Committee Member and Former MP, "Informant" (Interviewed by Hussein Alahmad, November 21, 2018).

59 Palestinian Writer and Columnist, "Informant" (Institute of Arab and Isalmic Studies: Interviewed by Hussein Alahmad, December 5, 2018). 
and political analysts to refute the Fatah narrative. Alarabiya similarly referred to knowledgeable politicians and key news analysts who are known for their harsh criticism of Hamas." ${ }^{\prime 60}$ Another party leader and PLO official emphasized how these channels "acted as mouthpieces for regional political elites and domestic parties." ${ }^{161}$ An exceptional example was given by a PASTV reporter: "A few months ago while on a live program Muntaha Al-Ramahi used the term "occupation" to describe Hamas' rule in the Gaza Strip." ${ }^{\prime 2}$ Most of PASTV channels adopted the narratives of the two main political parties and gave them more momentum to attract attention within the news. According to media analyst at a prominent policy research center: "Alarabiya and Aljazeera used to raise issues sharply contested between the two parties, like the resistance profile (the Hamas' weapon); the suspended salaries of Palestinian Authority employees in Gaza; the role of Palestinian Authority in blocking crossings to Gaza as a Hamas controlled area; the continuous health crisis in Gaza; the security coordination with Israeli forces, and so on. ${ }^{963}$

Another crucial issue discussed via PASTV journalism, and which was used to spark conflict and obstruct negotiations, is the existence of two security forces - Fatah's in West Bank and Hamas' in Gaza Strip. During the reconciliation negotiations, Fatah and pro-Saudi allies suggested the introduction of Fatah security into Gaza as a condition for a settlement, which Hamas categorially opposed. As part of a unity deal proposed in the 2011 Egyptian round of negotiations, the plan was to introduce 3,000 Fatah security officers to Gaza. The aim was to restore the influence of Fatah in Gaza and thus to loosen Hamas' control. Hamas refused the deal and the channels affiliated to Fatah, primarily the Egyptian channels, fiercely blamed Hamas. These channels focused their news media to suggest that Hamas was responsible for the failure of the deal. Meanwhile, the Hamas point of

60 Former Palestinian MP and Fatah Party Leader, "Former Palestinian MP and Fatah Party Leader."

${ }_{61}$ PLO Executive Committee Member and Former MP, "Informant."

62 Palestinian correspondent for a PASTV Channel, "Informant." This event took place on April $16^{\text {th }} 2017$ when during a talk show, Alarabiya host Muntaha Al-Ramahi fiercely faced-off against Hazem Qasem the Hamas spokesman, asking him: "But in the ten years that Hamas has been occupying the Gaza Strip - what has it achieved with regard to liberating historical Palestine?"

63 Palestinian Media Analyst at Key Policy Research Center, "Informant." 
view was communicated through Aljazeera. Thus, Palestinians received two contradictory narratives on the same event. Such complicated issues were raised (framed) and augmented within PASTV journalism to 'spoil' negotiations. For instance, during the 2012 reconciliation round sponsored by Qatar, there was an issue raised which was contested between Hamas and Fatah; this was the supervision of the management of the international fund allocated for the reconstruction of Gaza Strip in the aftermath of several Israeli wars on Gaza Strip. The issue was sufficient on several occasions to halt negotiations and delay reconstruction. The channels were referred to by politicians in the two parties as sources of information. Several times the decisions made were influenced by news content. As declared by a Fatah leader: “.... The channels' journalism was taken as source of information in the policy of the two parties." ${ }^{\prime 64}$ Another example of how these contested issues were raised and framed in news broadcasts, in a way to incite the two parties and engage them in public mobilization against each other, was given by a key media analyst addressing the Israeli pressures for the disarming of Hamas: "This was purely an interest for regional powers based on their regional agendas; pro-Oslo versus proResistance camp agendas." ${ }^{95}$ Such controversial stories were very sensitive at the public level, chiefly when raised in a 'timely' manner and emphasized through designated frames during news newscasts. Other issues, mainly those pertaining to the Palestinian Authority connections with Israel, were decisive when raised amid constant Israeli violations of the Oslo agreement in West Bank. There was concern about the violation of international laws, along with pivotal issues such as the status of Jerusalem in a final settlement and the constant, organized process of land confiscation and the expansion of settlements. As illustrated by a political writer: "Palestinian political actors relied on the channels' coverage to support their position and justify their behaviours and decisions in front of their public. We used to clearly see how the news content during reconciliation negotiations was always closely connected to the interests of regional political players in that negotiation round." ${ }^{\circ 6}$ By shrewdly framing/transforming the claims, interpretations and prescriptions of the two Palestinian parties into PASTV

${ }^{64}$ Former Palestinian MP and Fatah Party Leader, "Former Palestinian MP and Fatah Party Leader."

65 Palestinian Media Analyst at Key Policy Research Center, "Informant."

${ }_{66}$ Palestinian Writer and Columnist, "Informant." 
news media content and then amplifying this content to endow them with public attention and consonance, the PASTV channels were actually producing the 'news - propagative-value' that served regional political powers by supporting the political stand of their Palestinian allies and imposing their policies. Framing of news, as seen in this type of journalistic coverage embodied the key interests of the regional powers in the conflict. While attempting to promote these interests, PASTV journalism contributed decisively to the perpetuation of the status quo.

In my study, the textual framing analysis of Palestinian division news in PASTV primarily concentrated on 'hot stories,' chiefly those I determined best can contribute to representing the Palestinian sociopolitical and media landscape during the time frame of the study, among others: The spark of the conflict events, the major split event, the reconciliation process, the prolonged siege of Gaza Strip accompanied with several Israeli wars on Hamas, the 'Palestinian Papers,' in addition to some other relevant events. The textual analysis for these stories, as discussed in many quotes of my informants, shows how, through the amplification of one angle of the story, PASTV journalists intervened and framed news to shape public opinion and serve the ends of political elites. Framing helped these channels in promoting their 'sponsored' media culture and politically oriented discourse to become legitimate and natural in the eyes of millions of Arab viewers, including the divided Palestinians ${ }^{67}$ Within the low levels of democratic principle in the Arab world and the breaching of domestic media regulations, the new transnational journalistic culture was shaped by the socioeconomic and political systems in which the journalists operated ${ }^{68}$ With their skillful editorial teams, advanced communication technologies and excessive funds, key PASTV channels became capable of producing influential monopolies on transnational news media (which were within the hands of dominant political elites). With their regional and globally inclusive networks of reporters, key PASTV news channels became more powerful than other news outlets in attracting public attention and exerting

67 Barkho identified such aspects of legitimization and naturalization of shaped news in the coverage of pan-Arab channels involved in covering the ME, mainly the war in Iraq. See: Leon Barkho, News from the BBC, CNN, and Al-Jazeera: How the Three Broadcasters Cover the Middle East (Creskill, New Jersey: Hampton Press, 2010).

68 Lea Hellmueller, "Gatekeeping Beyond Geographical Borders: Developing an Analytical Model of Transnational Journalism Cultures," International Communication Gazette 79, no. 1 (2016): 4. 
media influence. The news messages within their journalism became laden with ideological and political influence and their 'news value' was appreciated by their supporting states and financers in proxy war and political competition.

\subsection{Tabloidization of News: Maximizing an Ally's Public Sympathy}

The discussion with many informants shows how both Palestinian parties sought propagative support from PASTV channels to promote public sympathy for their narrative amongst Palestinians as well as the Arab audience. For a bureau chief at a key PASTV channel, "Both parties looked on us as influential tools expected to serve their policy. Each side expected to receive our support; otherwise, we would be condemned either as 'infidels,' or 'traitors." "69 By describing journalists as 'infidels' and 'traitors, the informant rhetorically symbolized the position of Hamas and Fatah respectively. The two terms are employed as a means of semiotic resource to incorporate designated social and cultural meanings. ${ }^{70}$ The terms imply meanings used by the Palestinians when addressing those who cooperate with Israel, the occupier of their homeland. The two parties referred to the same meaning through two terms that stemmed from the ideological stance of each party. The term Infidels' stems from Hamas' religious ideology, while 'traitors' stems from Fatah's national secular ideology. Such terminology also reflects one face of fragmentation within the political culture, where Palestinian journalists were covering two conflicting ideologies that have associations within the two regional camps and their PASTV channels. Hence, both Palestinian parties relied heavily on PASTV channels to publicize their narrative and propaganda rivalry; the talk-shows and news casts were two platforms used by regional powers to exert their influence on Palestinian politics. "The two rival Palestinian parties relied on those platforms to polarize the Arab audience, also

69 Bureau Chief for Key PASTV Channel's office in Palestine, "Informant," ed. Hussein Alahmad (Interviewed by Hussein Alahmad, December 14, 2018).

70 According to Van Leeuwen: "Semiotic resources have a meaning potential, based on their past uses, and a set of affordances based on their possible uses, and these will be actualized in concrete social contexts where their use is subject to some form of semiotic regime" Theo van Leeuwen, Introducing Social Semiotics: An Introductory Textbook (London: Routledge, 2004). See also: Gunther Kress, Multimodality (London: Routledge, 2010). 
mobilize the Palestinians inside Palestine and those in the diaspora against each other." "'1 The transmission of political messages back and forth between regional and domestic powers was a crucial passage of political intervention highlighted by media scholars. They emphasized the huge capacity of regional and global media conglomerates to adapt, through such passage of communication, regional or even international political projects and interests to domestic contexts. ${ }^{72}$ Such interplay within panArab transnational media was likely to transmit news messages saturated (to various levels between channels) with political influence pertinent to the conflict and its developments. While regional powers employed PASTV journalism to intervene in the conflict and exert their influence and support their allies, the Palestinian parties also utilized the channels to communicate their position during the struggle. In certain contexts, messages were directed the other way towards the rival party and/or its affiliated regional camp; "If the Saudi Kingdom was leading the reconciliation process, then you would see Alarabiya promoting the initiative, while channels on the other side (like Aljazeera) were shrewdly working -behind the scenes, or directly- to obstruct the negotiations and throw doubt on their success. If Qatar was the sponsor, then Aljazeera will handle the promotion of that round as an achievement for the Qatari government. But you will also see Alarabiya and its sister channels, also the Egyptian channels working to frustrate the reconciliation attempt." ${ }^{\text {? }}$

Such contradictory coverage took place at these channels by, for example, sending messages criticizing Hamas and showing its leadership deliberately deceived and exploited by the Qatari regional agenda, while at the same time paying audience attention through the report to the strong connections between Qatar and the Muslim Brotherhood Movement (MBM)'s project in the region or even linking it to certain terrorist groups. ${ }^{74}$ Within their

${ }^{71}$ Palestinian Media Analyst at Key Policy Research Center, "Informant."

72 See: Lea Hellmueller, "Gatekeeping beyond Geographical Borders: Developing an Analytical Model of Transnational Journalism Cultures," International Communication Gazette 79, no. 1 (2016): 3, https://doi.org/10.1177/1748048516656304.

73 Dean at a Media Department in a Palestinian university, "Informant."

74 Sky News Arabic, "Qatar in Africa: The Role of Approved Terrorism" (Abu Dhabi: Sky News Arabic, 2017), https://www.skynewsarabia.com/middle-east/1006930. See also: DW Arabic, "(Translated from Arabic) Qatar Denies Saudi Arabia Confirms 'Evidence' of Doha Support for Terrorism” (Deutsche Welle, 2017), https://www. dw.com/ar/قطر -تنفي-و السعودية_تؤكد-وجود_أدلة_على_دعم_الدوحة_للإر هاب. 
contests for power and political gain, both regional camps involved PASTV news media discourse, primarily to exert their influence in support of their Palestinian ally or against his rival; "This formula of propaganda exchange was reflected in the split and perpetuated its existence. PASTV channels acted in a way that was exacerbating the conflict. Also, during the reconciliation process ..., it was a sponsor-oriented policy of coverage." ${ }^{\text {7 }}$

Late 2013, when General Sisi seized power through a military coup, against the MBM led government; Egyptian channels turned 180 degrees in support of the Fatah narrative and harshly attacked Hamas, oddly during the Israeli war on Gaza in 2014. However, Aljazeera, the powerful ally of Hamas, launched a fierce attack on the new Egyptian regime and its affiliated media, which then became a 'battle of the anchors' that "led to a war of words between Egyptian TV news anchors and their counterparts at Qatari-owned Al Jazeera." ${ }^{176}$ On several occasions the Egyptian Satellite TV newscasters slammed Hamas and its leadership and even termed the movement a 'terrorist group,' a term previously used by Israel to describe Hamas. For the first time in their history the Egyptian channels praised 'brave' Israel. ${ }^{77}$ Like other PASTV channels in oil-rich states, most Egyptian channels are established by economic conglomerates close to the regime. ${ }^{78}$ The few others, however, are captured by wealthy interests, political movements, or by the state apparatus. ${ }^{79}$ Notwithstanding, unlike other PASTV channels, the interplay between 'political logic' and 'news media logic' in Egyptian PASTV journalism took a different shape. Contrary to other PASTV channels (chiefly Aljazeera) that wind up state monopolies on information and steered an era of competitive PASTV journalism, Egyptian channels developed a comparatively rambunctious and cantankerous

75 Former Palestinian MP and Fatah Party Leader, "Former Palestinian MP and Fatah Party Leader."

76 "EgyptianAnchor Slams Hamas 'Terrorists', Praises 'brave'Israel," Battle of the Anchors (YNetnews.com, 2014), https://www.ynetnews.com/articles/0,7340,L-4558059,00. html.

77 "Egyptian Anchor Slams Hamas 'Terrorists', Praises 'brave' Israel."

78 Rasha Abdulla, "Egypt's Media in the Midst of Revolution" (Carnegie Endowment for International Peace, 2014), http://www.jstor.org/stable/resrep12802. See also: Marc Lynch, "After the Arab Spring: How the Media Trashed The Transitions," Journal of Democracy 26, no. 4 (2015): 94, https://doi.org/10.1353/jod.2015.0070.

79 Lynch, "After the Arab Spring" 92. 
political Satellite TV journalism, ${ }^{80}$ "that best correspond with domestic political narratives as they develop and change" ${ }^{81}$ This type of relationship that connects media structures with political and economic structures, and how that affects the media role, is emphasized by Herman and Chomsky. ${ }^{82}$ For them, this relationship makes a pivotal part in the analysis of the interaction between political systems and media structures (core thesis in mediatisation), because, according to Ostini and Fung, "these relationships and structures are integral to the content, distribution, and reception of information in a society." ${ }^{83}$ Interestingly, when compared to other PASTV channels, in how the 'news value' is incorporated in Egyptian Satellite TV journalism, such an appraisal facilitates the differentiation between media systems in Middle East that could be categorized as similar on the basis of levels of state influence, but different on the basis of institutional structures and levels/margins of editorial autonomy in these systems (E.g. Aljazeera vs Egyptian channels). It thus increases our understanding of media systems and the societies in which these systems operate.

\section{A Mediatised Bargain: 'Finance for the News Value'}

Finance was a major factor behind a channel's adherence and adoption of its financer's political stance towards the Palestinian parties. A statement by a prominent media analyst noted: "There are two key principal factors behind their adaption, which also determined their editorial policy - the ownership and the financing source for those channels." ${ }^{84}$ A Palestinian political writer has a similar rationale: "Finance is the crucial factor. Traditionally, for many decades now, the persistent dilemma in the Arab world is the absence of independent media." ${ }^{85}$ Another party leader stated:

\footnotetext{
80 Lynch, "After the Arab Spring" 92.

81 Basil El-Dabh, "Conflating Hamas and Palestine in the Egyptian Media" (Washington, DC : The Tahrir Institute for Middle East Policy, 2014), https://timep.org/commentary/ analysis/conflating-hamas-palestine-egyptian-media/.

82 Noam Chomsky, "A Propaganda Model," in Manufacturing Consent: The Political Economy of the Mass Media (New York, USA: Pantheon Books, 1988), 43.

83 Ostini and Fung, "Beyond the Four Theories of the Press: A New Model of National Media Systems," 56.

84 Palestinian Media Analyst at Key Policy Research Center, "Informant."

85 Palestinian Writer and Columnist, "Informant."
} 
"Finance for those channels comes from the states that sponsor them; within the non-democratic system of those states, they have to follow the line of their governments. The courage, let us say the candor, with which they address the 'other' is not reflected in their journalism." ${ }^{86}$

In addition to finance, repressive Arab regimes threatened counterhegemonic styles of news media, an so these channels sought protection from states hosting them or political elites in the region, which came at the expense of their sovereignty and objectivity, as stated by an MP: "Those channels pay the pill for their operation over certain geographic areas. ${ }^{\prime 87} \mathrm{In}$ a new world political system, power is exercised through means other than conventional military intervention, as in the case of politically amateurish Gulf States, small, but rich and eager to play 'big' politics. ${ }^{88}$ The role PASTV channels played during the Arab uprisings brought to an end several entrenched regimes, which previously very few had dared to dream would happen. Furthermore, during the recent Qatari crisis, GCC states requested the closure of Aljazeera as a condition before a settlement could take place. This event emphasized the powerful role of PASTV journalistic intervention in the politics of the region.

The evident and strong correlation between ownership and finance make them main determinants for the channels behavior. There is also the ideological dimension that fuels the loyalty of these channels; Aljazeera to the MBM, Almayadeen to the Iranian camp, and Alarabiya to the Saudi agenda. Loyalty, however, is not a choice for these channels as much as it is compliance with their financers, especially as these channels are owned by political powers or share corporate economics linked to the ruling families. There was also the automatic loyalty of those who desired to work for these channels. This was a key issue confirmed by a senior editorial staff member at a PASTV channel; he openly stated: "It's not plausible to imagine that sponsored stations may contradict the agenda of their donors. ${ }^{89}$ For another

\footnotetext{
86 PLO Executive Committee Member and Former MP, "Informant."

87 PLO Executive Committee Member and Former MP.

88 Simon Henderson, "Understanding the Gulf States," NFocus Quarterly, no. Spring (2014), https://www.washingtoninstitute.org/policy-analysis/view/understanding-thegulf-states.

89 Reference is anonymously quoted so as to fulfil the consent form signed with the interviewee, according to the ethics standards of the Research Ethics Approval at the Arab American University.
} 
informant, staff loyalty is nonnegotiable, it is "take it or leave it." ${ }^{\prime 90}$ This issue was also noted by another correspondent at another key channel: "Of course the channels' policies are influenced by their financers; nobody will support or finance a channel that will talk against him." ${ }^{11}$

Arguably, the political interests discussed in the previous sections formed the core of the deal between the channels and their financers. Consequently, meeting these interests was crucial for the sustainability of each channel. Finance was one key determinant for a channel's policy. Interesting evidence came from the bureau chief for a key PASTV channel: "Channels need finance, and finance comes from two directions: from a political power, or from a commercial interest." ${ }^{.92}$ When asked how his channel dealt with its financer/state's priorities while covering the conflict, he answered: "It is axiomatic for the channel to adopt financier's interests. Practically, it's not plausible to imagine that sponsored stations may oppose a donor's agenda." ${ }^{93}$ Similarly, clear answers were also offered by other PASTV staff and correspondents: "In such a dictatorial context as in the Arab world, pan-Arab channels weren't able to avoid the morass of affiliation, and of course this was at the expense of their objectivity and professional conduct. [...] So, their editorial policy is under high pressure, despite many of their senior staff being Palestinians (mainly at Aljazeera and Alarabiya); they have to stay loyal to the policy of their channel in order to maintain their jobs." 94

The financial risk also threatened the sustainability of channels. PASTV channels are neither able nor prepared to survive without subsidies from the state or political elites. However, the huge funds offered by political powers weren't mere grants offered by philanthropists. There was a precious price to guarantee the cash-flow; channels had to deliver high degrees of loyalty and sufficient services for the political powers, whilst also supporting their political interests in the region, particularly the Palestinian split, as a central issue in the ME. To gain the funding channels

90 Trustee for a Regional Media Agency, "Informant" (Interviewed by Hussein Alahmad, November 23, 2018).

91 Palestinian correspondent for a PASTV Channel, "Informant."

92 Bureau Chief for Key PASTV Channel's office in Palestine, "Informant."

93 Bureau Chief for Key PASTV Channel's office in Palestine.

94 Palestinian Media Analyst at Key Policy Research Center, "Informant." 
needed, a desired news value should both tactfully and influentially serve the political agendas of their donors. The channels produced the 'news value' to satisfactorily meet the political desires of their financers. Thus, the channels adopted the two parties' narratives and raced to create stories and publicize them. They were empowered by skillful staff and high-tech facilities in an attempt to remain superior in their news coverage. The more they created news value and attracted attention, the more they satisfied their financers: "The more the channel is powerful and influential, the more it is targeted by the regional powers. ${ }^{\circ 5}$ For an NGO media reporter, news aptitude to gain attention was a must in order to get the money: "There were high levels of competition between those news networks for quality of news to maximize their market share of audience [attention], for which, as well as channel loyalty, oil rich states have the capacity to bargain funds. According to what we used to see; the channels were willing to do that." A channel's voice represented the voice of the regional actor behind it; a formula that embodied a 'finance for news value' bargain. The policy makers and top managers at the PASTV channels were an integral part of the ruling families or their retinue. So, they acted as pressure shifters shifting pressure from the state down to the editorial team members, who shift it down further to their staff and field reporters. ${ }^{97}$ This was the 'moneyfor-news/propagative value' interaction where conflict incidents and party narratives offered raw material for the editorial to keep top management satisfied, and thus maintaining their 'serious' salaries.

\section{Conclusion}

The article explored how during the Palestinian internal conflict, given the high levels of interaction between regional and domestic political actors involved in PASTV journalism, news value rose significantly and was in high demand for political purposes. However, from the informants' perspective, manufacturing the news value in PASTV journalism was a

\footnotetext{
95 Bureau Chief for Key PASTV Channel's office in Palestine, "Informant."

96 Palestinian Media Reporter at an NGO, "Informant."

97 See: Leon Barkho, "The Discursive and Social Power of News Discourse: The Case of Aljazeera in Comparison and Parallel with the BBC and CNN," Studies in Language \& Capitalism 3, no. 4 (2008): 11-159, http://languageandcapitalism.info. See also: Wojcieszak, "Al-Jazeera: A Challenge to Traditional Framing Research.”
} 
financial requirement, which meant that the operation and survival of the channels were in the hands of their financers, sponsors or hosting states. Accordingly, the fluctuating policies and unpredictable behavior of regional powers were hazardously reflected in the quality of PASTV journalism. The article examined the valuable function of news production in framing information and shaping the perceptions of the Palestinian public. In the Palestinian split this was a valuable service that PASTV channels provided; it was an appreciated propagative value for regional political elites, who were in a proxy-competition within the Palestinian split. Both Palestinian parties had deep connections to regional agendas and political actors on both sides sought external support, chiefly to socialize their narrative and gain local and regional sympathy, but also to polarize and mobilize against each other. Both regional and domestic political actors were interested in two specific aspects of PASTV journalism. Firstly, the journalism could reinforce the clout and political stand of the Palestinian ally. Secondly, the journalism could increase public sympathy with the domestic ally within both the domestic and regional public spheres. From a journalistic perspective, in order to achieve these aims, the channels framed the news in a way to enhance the two contradictory Palestinian narratives in their news, and then amplify them to attract public attention. The channels aimed to achieve their financers' political interests by producing news value capable of attracting and shaping public opinion, serving these interests. The primary aim of the channels was to gain the finance which was vitally needed to cover their huge operational costs.

The interplay between politics and news media forms the core discussion in the theory of the mediatisation of politics, which refers to such interplay as a struggle between 'political logic' and 'news media logic'. Mediatisation theorizes that, such interplay is likely to be guided by the more powerful of the two logics, while the other logic adheres. The article examined the interrelationship between politics and news media as an interaction process based on mutual benefit exchange, and explained how the correlation between the two different, albeit interconnected, systems of news media and politics occurred; how 'political logic' colonized 'news media logic. Such interplay incorporates the difference between "neutral" and "participant" 
journalism..$^{98}$ The interplay between political logic and news media logic was imbalanced and resulted in the logic of acquiescence in the channels' policies. This was in contrast to working in tandem -as proposed by some media scholars- ${ }^{99}$ and constructively forming the logic of appropriateness in support of political integrity and social cohesion (Social Responsibility theory). ${ }^{100}$ This was embodied in the interventional way PASTV channels covered the Palestinian split, serving the ends of competing political powers, and the perpetuation of the conflict was a disastrous consequence.

Contrary to Strömbäck's postulations regards media's independency of political institutions, and how it shifts to play the 'Fourth Estate' role, ${ }^{101}$ the analysis of the interplay between political logic and news media logic in PASTV coverage of Palestinian split shows how degrees of democracy and the quality of Satellite TV journalism are entwined. Once traditional Arab state-run TV news media became invalid in a globalized world of high modernity, rentier and despotic Arab regimes not only managed to tame the momentum of the 21 st century's generation of counter hegemonic transnational STV journalism, but also to turn it back into a desired model of state-run satellite TV news media.

The round-the-clock coverage that these channels gave to certain events, whilst neglecting others which had equal newsworthiness, shows how issues relating to autonomy (such as 'grant-in-aid' with an imprint on key appointments at these channels), were likely to give a hosting state the opportunity to control channel editorials. The purpose of such influence is to promote the narrative of the ally and support his political stand and to refute or even efface the narrative of his rival, at the expense of reality. This is one crucial factor (amongst others) that lies behind the frustration of several reconciliation attempts and the perpetuation of the split.

98 John W C Johnstone and William W Bowman, "The Professional Values of American Newsmen,” The Public Opinion Quarterly 36, no. 4 (1972): 522.

99 See: March and Olsen, Rediscovering Institutions, (1989). See also: Toril Aalberg, Jesper Strömbäck, and Claes H de Vreese, "The Framing of Politics as Strategy and Game: A Review of Concepts, Operationalizations and Key Findings," Journalism 13, no. 2 (2011): 162-78, https://doi.org/10.1177/1464884911427799.

100 Ostini and Fung, "Beyond the Four Theories of the Press: A New Model of National Media Systems," (2002).

101 Strömbäck, "Four Phases of Mediatization." 
Such submission of the PASTV channels to the political powers is attributed to the seductive subsidies on offer. The channels utilized the money to recruit highly skilful staff and advanced equipment to facilitate wide-ranging coverage and state-of-the-art broadcasting services. Such a correlation is a reminder of the ancient paradigm of Arab state-run media, which supposedly lost its role (although potentially not) with the advent of PASTV journalism. On the ground, with the lack of democracy and free media, PASTV journalistic logic submitted to regional political logic, and the 'oscillating' journalism of Egyptian channels provided a fitting example on how such docility occurred. PASTV journalism fought to achieve proxy-victories without much consideration for professional and ethical standards, even when this facilitated the demolition of the nacent democratic experiments within Palestinian history (as with the entirety of the Arab world). The continuity of the split is an utmost threat for Palestinians in their struggle for self-determination, against their Westernbacked occupier, as the major beneficiary from the conflict perpetuation.

\section{Bibliography}

Aalberg, Toril, Jesper Strömbäck, and Claes H de Vreese. "The Framing of Politics as Strategy and Game: A Review of Concepts, Operationalizations and Key Findings." Journalism 13, no. 2 (2011): 162-78. https://doi.org/10.1177/1464884911427799.

Abdulla, Rasha. "Egypt's Media in the Midst of Revolution." Carnegie Endowment for International Peace, 2014. http://www.jstor.org/stable/ resrep12802.

Andreas, Hepp, and Friedrich Krotz. Mediatized Worlds: Culture and Society in a Media Age. UK: Palgrave Macmillan, 2014. https://doi. org/10.1177/0163443716667063.

Armbrust, Walter. "A History of New Media in the Arab Middle East." Journal for Cultural Research 16, no. 2-3 (2012): 155-74. https://doi. org/10.1080/14797585.2012.647666.

Asp, Kent. Massmedier Mäktiga: Studier i Politisk Opinionsbildning Powerful Mass Media: Studies in Political Opinion-Formation. Stockholm: Akademilitteratur, 1986. 
Barkho, Leon. "The Discursive and Social Power of News Discourse: The Case of Aljazeera in Comparison and Parallel with the BBC and CNN." Studies in Language \& Capitalism 3, no. 4 (2008): 11-159. http://languageandcapitalism.info.

Bureau Chief for Key PASTV Channel's office in Palestine. "Informant." Edited by Hussein Alahmad. Interviewed by Hussein Alahmad, December 14, 2018.

Chomsky, Noam. "A Propaganda Model." In Manufacturing Consent: The Political Economy of the Mass Media , 43-69. New York, USA: Pantheon Books, 1988.

Cottle, Simon. Mediatized Conflict: Developments in Media and Conflict Studies. UK, Glasgow: Open University Press, 2006.

Dean at a Media Department in a Palestinian university. "Informant." Interviewed by Hussein Alahmad, December 13, 2018.

Dean at a Palestinian Media College. "Informant." Interview by Hussein Alahmad, November 21, 2018.

Director of a Palestinian Center for the Protection of Press Freedom. "Informant." Interviewed by Hussein Alahmad, December 24, 2018.

Durham, Meenakshi G, and Douglas M Kellner. Media and Cultural Studies. Malden, MA, USA; Oxford, UK; Carlton, Australia: Blackwell Publishing, 2006.

DW Arabic. "(Translated from Arabic) Qatar Denies Saudi Arabia Confirms 'Evidence' of Doha Support for Terrorism." Deutsche Welle,

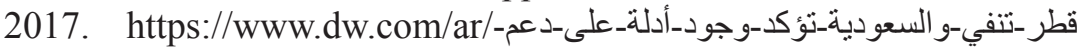

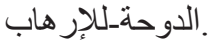

“Egyptian Anchor Slams Hamas 'Terrorists', Praises 'brave' Israel." Battle of the Anchors. YNetnews.com, 2014. https://www.ynetnews.com/ articles/0,7340,L-4558059,00.html.

El-Dabh, Basil. "Conflating Hamas and Palestine in the Egyptian Media." Washington, DC : The Tahrir Institute for Middle East Policy, 2014. https://timep.org/commentary/analysis/conflating-hamas-palestineegyptian-media/.

Entman, Robert. "Framing: Toward Clarification of a Fractured Paradigm." Journal of Communication 43, no. 4 (1993): 51-58. 
Esser, Frank. "Metacoverage of Mediated Wars: How the Press Framed the Role of the News Media and of Military News Management in the Iraq Wars of 1991 and 2003." American Behavioral Scientist 52, no. 5 (2009): 709-34. http://online.sagepub.com.

Former Palestinian MP and Fatah Party Leader. "Former Palestinian MP and Fatah Party Leader." Ramalla, Palestine: Interview by Hussein Alahmad, November 28, 2018, 2018.

Ghanem, As'ad. The Palestinian Regime: A "Partial Democracy." Brighton, Portland: Sussex Academic Press, 2001.

H. Elmasry, Mohamad, Alaa El Shamy, Peter Manning, Andrew Mills, and PhilipAuter. "Al-Jazeera and Al-Arabiya Framing of the Israel-Palestine Conflict during War and Calm Periods." Communication Gazette 75 (2013): 750-68. https://doi.org/10.1177/1748048513482545.

Hellmueller, Lea. "Gatekeeping beyond Geographical Borders: Developing an Analytical Model of Transnational Journalism Cultures." International Communication Gazette 79, no. 1 (2016): 3-25. https:// doi.org/10.1177/1748048516656304.

Henderson, Simon. "Understanding the Gulf States." NFocus Quarterly, no. Spring (2014). https://www.washingtoninstitute.org/policyanalysis/view/understanding-the-gulf-states.

Herman, Edward, and Noam Chomsky. "A Propaganda Model (Excerpted from Manufacturing Consent: The Political Economy of the Mass Media)." https://chomsky.info, 1988. https://chomsky.info/consent01/.

- Manufacturing Consent: The Political Economy of the Mass Media. New York, USA: Pantheon Books, 1988.

Iyengar, Shanto, and Donald R Kinder. News That Matters: Television and American Opinion. Chicago, IL, US: University of Chicago Press, 1987.

Jenssen, Anders T. Den Medialiserte Politikken [Mediatized Politics]. Oslo: Universitetsforlaget, 2007.

Johnstone, John W C, and William W Bowman. "The Professional Values of American Newsmen." The Public Opinion Quarterly 36, no. 4 (1972): 522-40. 
Kress, Gunther. Multimodality. London: Routledge, 2010.

Leeuwen, Theo van. Introducing Social Semiotics: An Introductory Textbook. London: Routledge, 2004.

Leihs, Nadia, and Maria Roeder-Tzellos. "Political Communication Research in the Middle East." In The International Encyclopedia of Political Communication, 1-8. NJ, United States: John Wiley \& Sons, Inc., 2015. https://doi.org/10.1002/9781118541555.wbiepc211.

Lilleker, Darren G. "Mediatization." In Key Concepts in Political Communications, 117-21. London: SAGE, 2008. http://dx.doi. org/10.4135/9781446212943.n29.

Lynch, Marc. "After the Arab Spring: How the Media Trashed The Transitions." Journal of Democracy 26, no. 4 (2015): 90-100. https:// doi.org/10.1353/jod.2015.0070.

. "Shattering the 'Politics of Silence': Satellite Television Talk Shows and the Transformation of Arab Political Culture." Washington, DC: SADA: Carnegie Endowment for International Peace, 2008. http:// carnegieendowment.org/sada/?fa $=21036$.

Meyer, Christoph O, Christian Baden, and Marie-Soleil Frère. "Navigating the Complexities of Media Roles in Conflict: The INFOCORE Approach." Media, War \& Conflict 11, no. 1 (2017): 3-21. https://doi. org/10.1177/1750635217719754.

National Democratic Institute for International Affairs. "Final Report on the Palestinian Legislative Council Elections." Washington DC: national democratic institute, 2006.

O’Neill, Deirdre. "What Is News?" Journalism Studies 18, no. 12 (2017): 1470-88. https://doi.org/https://doi.org/10.1080/146167 0X.2016.1150193.

O’Neill, Deirdre, and Tony Harcup. "News Values and Selectivity." In Handbook of Journalism Studies, edited by T Hanitzsch, 161-74. Hoboken, NJ: Routledge, 2009.

Ostini, Jennifer, and Anthony Y.H. Fung. "Beyond the Four Theories of the Press: A New Model of National Media Systems." Mass Communication and Society 5, no. 1 (2002): 41-56. http://dx.doi. org/10.1207/S15327825MCS0501_4. 
Palestinian Columnist and News Analyst. "Informant." Interviewed by Hussein Alahmad, December 19, 2019, 2018.

Palestinian correspondent for a PASTV Channel. "Informant." Interviewed by Hussein Alahmad, December 14, 2018.

Palestinian Media Analyst at Key Policy Research Center. "Informant." Edited by Hussein Alahmad. Interviewed by Hussein Alahmad, November 23, 2018.

Palestinian Media Reporter at an NGO. "Informant." Edited by Hussein Alahmad. Interviewed by Hussein Alahmad, November 27, 2018.

Palestinian Writer and Columnist. "Informant." Institute of Arab and Isalmic Studies: Interviewed by Hussein Alahmad, December 5, 2018.

PLO Executive Committee Member and Former MP. "Informant." Interviewed by Hussein Alahmad, November 21, 2018.

Rinnawi, Khalil. Instant Nationalism: McArabism, Al-Jazeera, and Transnational Media in the Arab World. University Press of America, 2006. https://books.google.ps/books?id=xJYLNUBgSeUC.

Rugh, William A. Arab Mass Media: Newspapers, Radio, and Television in Arab Politics. Westport, CT: Praeger, 2004.

Schulz, Winfried. "Reconstructing Mediatization as an Analytical Concept." European Journal of Communication 19, no. 1 (2004): 87101. https://doi.org/10.1177/0267323104040696.

Shendurnikar, Nidhi, and Simon Cottle. Mediatized Conflict: Developments in Media and Conflict Studies. Edited by Simon Cottle. UK: Open University Press, 2006.

Sky News Arabic. "Qatar in Africa: The Role of Approved Terrorism." Abu Dhabi: Sky News Arabic, 2017. https://www.skynewsarabia.com/ middle-east/1006930.

Strömbäck, Jesper. "Four Phases of Mediatization. An Analysis of the Mediatization of Politics'." The International Journal of Press/Politics 13, no. 3 (2008): 228-46. https://doi.org/10.1177/1940161208319097.

Strömbäck, Jesper, and Frank Esser. "Shaping Politics: Mediatization and Media Interventionism." In Mediatization. Concept, Changes, Consequences, edited by Knut Lundby. New York: Peter Lang, 2009. https://doi.org/10.5167/uzh-29325. 
Strömbäck, Jesper, and Lars W Nord. "Do Politicians Lead the Tango?" European Journal of Communication 21, no. 2 (2006): 147-64.

Thompson, John B. The Rise of Mediated Interaction . UK: Cambridge, 1995.

Trustee for a Regional Media Agency. "Informant." Interviewed by Hussein Alahmad, November 23, 2018.

Vreese, Claes H de. "Mediatization of News: The Role of Journalistic Framing." In Mediatization of Politics: Understanding the Transformation of Western Democracies, edited by Frank Esser and Jesper Strömbäck, 137-55. London: Palgrave Macmillan UK, 2014. https://doi.org/10.1057/9781137275844_8.

Wojcieszak, Magdalena. "Al-Jazeera: A Challenge to Traditional Framing Research." The International Communication Gazette 69, no. 2 (2007): 115-28. 